\title{
Tracking on-farm innovations to unearth alternatives to the dominant soybean-based system in the Argentinean Pampa
}

\author{
Chloe Salembier $^{1}$ • Julio Horacio Elverdin ${ }^{2}$ Jean-Marc Meynard ${ }^{3,4}$
}

Accepted: 17 November 2015/Published online: 15 December 2015

(C) INRA and Springer-Verlag France 2015

\begin{abstract}
Farming activities in the Argentinean Pampa have focused on soybean production since the 1990s. The resulting cropping systems may not be sustainable in the long run due to development of glyphosate-tolerant weeds, homogenization of landscape mosaics, and pollutions. Here, we used the tracking on-farm innovation method to produce resources for the design of alternatives. The five steps of tracking on-farm innovation were (1) characterization of the soybean-based dominant cropping system, (2) identification of producers developing alternative systems, (3) description of these cropping systems and their agronomic logic, which is the link between the producer practices and their motives when choosing these practices, (4) multicriteria assessment of the performances of the systems, and (5) analysis of the development conditions of the most efficient systems. We identified 22 alternative cropping systems developed by farmers. These systems all include original practices: diversification of crop rotations (22 cases), occasional return to tillage (15 cases), and low pesticide use (16 cases). Some alternative systems were more sustainable than the soybean-based system, as shown by lower economic risk level, better ability to maintain soil organic carbon content, and less glyphosate-tolerant weeds. Our
\end{abstract}

Chloe Salembier

Chloe.salembier@supagro.inra.fr

1 INRA, UE0411 Alénya Roussillon, Mas Blanc, 66200 Alénya, France

2 INTA, Balcarce Integrated Unit, C.C. 276, 7620 Balcarce, Buenos Aires Province, Argentina

3 INRA, UMR 1048 SAD APT, F-78850 Thiverval-Grignon, France

4 AgroParisTech, UMR 1048 SAD APT, F-78850 Thiverval-Grignon, France results show overall that tracking on-farm innovations is an efficient method to get references on alternative cropping systems developed by farmers.

Keywords Crop diversification · GMO soybean ·

Monoculture · Direct seeding · On-farm innovation · Tracking innovations · Glyphosate-tolerant weeds $\cdot$ Woodlouse

\section{Introduction}

In agriculture, the farmer himself is an important source of innovations: while it is true that varietal and agrochemical innovations usually come from large firms, farmers have often been responsible for the emergence of innovative cropping or livestock systems. As underlined by Goulet et al. (2008), "the farmers are permanently adjusting their action and their knowledge; they adapt to changes and sometimes create technical and organizational innovations which can then be taken up by others." Agroecology theorists emphasize the farmers' capacity for innovation, insisting on their ability to combine empirical and scientific knowledge in the design of their systems (Altieri et al. 2012).

These on-farm innovations are now seen as resources to support a more massive development of sustainable farming practices. Generally speaking, identifying on-farm innovations and analyzing them to determine which ones are the most interesting is a way of building references on alternative systems (Feike et al. 2010; Petit et al. 2012; Meynard et al. 2012): we call this approach «tracking on-farm innovations». In this article, we used this approach to identify cropping systems in the Argentinean Pampa that have been developed by producers, providing an alternative to the quasimonoculture of soybean, whose environmental limits are becoming increasingly obvious. 
In the Pampa, farming activities have been specialized in soybean production since the 1990s. This specialization, commonly called "sojización," gathered pace when glyphosatetolerant transgenic varieties of soybean were marketed, associated in a technological package with glyphosate and direct seeding. For a producer, there are many advantages in soybean cultivation (Fig. 1), not only agronomic and economic but organizational too. This crop is very adaptable and can be grown in a wide variety of soil and climatic environments (Andrade and Sadras 2002). By mobilizing this easy-to-use technological package, the producer (i) is free from the problem of weeds (use of glyphosate), (ii) limits risks of erosion and direct evaporation of the soil thanks to direct seeding (Castilla 2013), and (iii) spends less time on his land by eliminating certain tasks (mechanical weed management, tillage). The soybean is exported all over the world to a rapidly expanding market and is reputed to be a crop with very few risks. Since the 1990s, these multiple advantages have encouraged many farmers to specialize in this crop, which is becoming the pivot of rotations and is often sown every year on the same plots of land (Filloy and Bellocq 2007).

For several years, non-governmental organizations, researchers, agricultural advisors, and the producers themselves have questioned the sustainability (both agri-environmental and social) of cropping systems specializing in soybean and are talking about the need to find alternatives (Elverdín et al. 2011; Botta et al. 2011). This specialization has repercussions on the territorial dynamic of the Pampa region (Albaladejo 2011); in particular, there is an increasing migration from the countryside towards the cities and local farming know-how that has not been written down is being lost (Hernández 2009). The development of monocultures or quasi-monocultures generates a homogenization of landscape mosaics, with implications for the ecosystem services related to biodiversity (Benton et al. 2003; Barral and Maceira 2012) and encouraging an increase in health risks at territory level. These simplified practices involve the repeated use of glyphosate, which can build up tolerance in some weeds (Avena fatua, Sorghum Halepense), causing the producer to resort to the use of even more herbicides. The conversion of semi-natural grasslands into fields of cereals and oilseeds, associated with input-

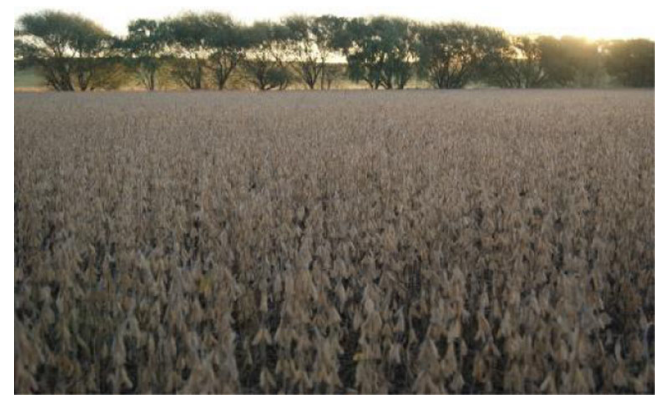

Fig. 1 Soybean field before harvest in the Argentinean Pampa, April 2013, authors' source intensive crop managements, favors greenhouse gas emissions (Carreño et al. 2010) and contributes to the pollution of groundwater (Costa et al. 2010). Soybean residues provide the soil with very little organic carbon, and studies reveal that, over the medium term, as soon as the rotation includes frequent crops of soybean, the humus content in the soil decreases, in spite of direct seeding (Studdert and Echeverria 2000).

The sojización is often defined as a process of standardization of farming practices in the territories, but some uncommon cropping systems could be erased by the general descriptions of this process. The work presented in this article is based on the hypothesis that some producers in the Pampa have developed more environmentally friendly cropping systems than the dominant system based on soybean. After presenting and assessing various alternative systems, all far from frequent in the region, we will discuss their interest for regional agriculture and the lessons they inspire for agricultural research and development.

\section{Material and method}

\subsection{Characteristics of the study area}

This work was carried out in 2012-2013 in the district of Balcarce $\left(37^{\circ} 50 \mathrm{~S}-58^{\circ} 15 \mathrm{~W}\right)$, in the south-east of the Buenos Aires province. This district is characterized by a climate of the temperate moderate oceanic type, with average annual rainfall distributed over 90 days a year $(900 \mathrm{~mm}$ water deficit in summer and surplus in winter) and annual average temperatures of $14^{\circ} \mathrm{C}\left(\max .21^{\circ} \mathrm{C}-\min .7 .5^{\circ} \mathrm{C}\right)$ (Monaco and Laclau 2013). The soils are mainly Mollisols, which have a very high organic content ( 5 to $7 \%$ ) because they have long been occupied by extensive grasslands. All the cropping systems we studied were developed on this soil type.

\subsection{Method for identifying, characterizing, and assessing alternative cropping systems developed by producers}

This work of tracking alternative cropping systems is broken down into 5 principal stages: (1) characterization of the most widespread cropping system in the study area (known as "dominant system"), (2) identification of producers developing alternative systems, (3) description of these cropping systems and their agronomic logic, (4) multicriteria assessment of the performances of the alternative cropping systems, compared to the dominant system, and (5) analysis of the conditions for developing the most efficient systems and their potential interest for the future.

Stage 1: through semi-directed interviews, three advisors, an agricultural contractor, two producers, and two researchers described to us in the same terms the cropping system which, 
they said, occupied most of the cultivable land in the district of Balcarce, as well as the motives which led different producers to implement it. This cropping system where soybean returns each year to the same field has been used in this work as a "reference" to identify alternative systems.

Stage 2: our objective in this stage is not to obtain an exhaustive sample of all the producers who would develop alternative cropping systems but to identify a diversity of atypical cases. For this, we mobilized the so-called snowball sampling procedure. We contacted actors working in different networks (researchers of the Argentinean national institute for agronomic research, public and private agricultural advisors, agricultural contractors, producer associations, farmers) to help us identify farmers whose practices differ from the dominant system. This exploration was conducted via the following questions: "Do you know producers whose practices differ from the dominant system? Otherwise, do you know someone who might know such producers?" Step by step, we were directed towards 22 producers; 15 of them were interviewed, as several of their practices differed from the dominant system.

Stage 3: once these producers were identified, we set out (still through semi-directed interviews) to describe their alternative cropping systems. The interview aimed at collecting the information necessary for the analysis of the agronomic logic of each system: (i) the practices (crop rotation, cultivation methods by species) and (ii) the motives which led producers to implement these practices. After analyzing the agronomic logic of each cropping system, we classified them according to the most significant explanatory variables (practices and motives) of their logic.

Stage 4: the multicriteria assessment aims at comparing the performances of the five types of alternative systems, among themselves and with the dominant system. The chosen assessment indicators correspond to the criteria used by the producers to evaluate their practices (criteria expressed during the explanation of their motives - stage 3), complemented by criteria making it possible to evaluate the agroenvironmental sustainability of the systems. The 12 indicators used in this work were as follows:

- An indicator of glyphosate-tolerant weed development (Tolerance): the data on this qualitative indicator were collected during discussions with producers. The cropping systems were classified into three categories: (1) no presence of tolerant weeds noted in the fields by the farmer; (2) presence of tolerant weeds having no impact on practices; and (3) presence of tolerant weeds considered as harmful by the farmer and involving the application on soybean of other herbicides (in addition to glyphosate).

- The Treatment Frequency Index (TFI) (Brunet et al. 2007): the TFI reflects the frequency of use of plant health products in agriculture. The calculation takes into consideration all of the years of the rotation (arable crops and grasslands). TFI field $=\sum \mathrm{t}[(\mathrm{DAt} / \mathrm{DR} \mathrm{t}) \times \mathrm{Pt}]$, with «DAt» the dose actually applied for treatment $t$, «DRt» the dose recommended by the Argentinean plant health product guide for the same pesticide on the same crop (Cámara de sanidad agropecuaria y fertilizantes 2007), and $\langle\mathrm{Pt}\rangle$ the ratio of the surface treated on the total surface of the field for treatment $t$. We also calculated the TFI "herbicides" and the TFI "without herbicides," reflecting the intensity of cumulated use of fungicides and insecticides.

- The indicator of the evolution of organic carbon content in the soil IOC $(\mathrm{kg} \mathrm{C} / \mathrm{ha})$ which is calculated by the SIMEOS-AMG software developed by Duparque et al. (2011). This tool, produced from work by Andriulo et al. (1999) in Argentina and France, simulates, over 50 years, the evolution of the carbon content of soils at the scale of a field for a given cropping system.

- The indicators of ammonia volatilization, nitrogen protoxide emissions, nitrate leaching, and energy consumption. These indicators assess the nitrogen pollution and energy consumptions at field level for a given cropping system. They are calculated, over the whole rotation, using the CRITER software, mobilizing the INDIGO $^{\circledR}$ V2.0 method (Bockstaller et al. 1997).

- The gross added value (GAV) (\$/ha) for arable crops: this results from the difference between gross product and intermediate consumptions. The intermediate consumptions include all of the costs associated with inputs and labor (price of agricultural contractors provided by Asociación Argentina de Consorcios Regionales de Experimentación Agrícola-AACREA—of Mar y Sierras). The calculation mobilizes the average outputs per crop provided by the producers, and the sales prices (inter-annual averages from 2003 to 2012, prices provided by the "serie de precios agropecuarios AACREA" Program). For annual fodder crops of 3 to 4 months included in certain rotations, the gross product is calculated on the average weight of meat produced per hectare in the case of a beef cattle farm (oats $135 \mathrm{~kg} / \mathrm{ha}$, rye-grass $220 \mathrm{~kg} / \mathrm{ha}$, sorghum $216 \mathrm{~kg} / \mathrm{ha}$ ) and on an inter-annual average of the sales prices of meat per kilo (from 2003 to 2012, provided by AACREA). In the case of rotations integrating multiannual grasslands, the annual average result was only calculated over the years of arable crops, as the calculation depended too heavily on herd management.

- The return on investment $(\mathrm{ROI})(\$ / \$)$ : this is the ratio between the gross added value and the intermediate consumptions at the level of the cropping system. The data mobilized are the same as for the calculation of the gross added value. For rotations including multiannual 
grasslands, the calculation was only made over the years of arable crops. The years of potato cropping were not integrated into the calculation either, insofar as the gross added value gained during those years came from the revenue generated by renting fields to a third party who produced potatoes.

- The risk indicator (\%): for a given cropping system, this is the coefficient of variation calculated on the basis of interannual variations in yields and prices for each crop in the rotation (except for the multiannual grasslands). This indicator was calculated using the @ RISK $^{\circledR}$ software. The references of variability of prices and yields are those of the AACREA for the "Mar y Sierras" region of the province of Buenos Aires.

- Land use intensity (\%): this is the percentage of land occupation in months by crops (cereals, oilseeds, fodder) or grasslands over the year. It reflects the intensification level of land use.

Stage 5: this stage aims at learning the lessons, for agricultural research and development, of the results of the four previous stages: what are the conditions for developing the most effective alternative systems? How could these systems enrich the development of references or provide additional research questions.

\section{Results and discussion}

\subsection{Description of the agronomic logic of the dominant cropping system (stage 1)}

The dominant cropping system, described in 2012 and 2013 by the various actors surveyed in the district of Balcarce, is characterized by a rotation of three crops over 2 years: long cycle soybean the first year (from November to May), a cereal the second year (wheat or barley, according to market prices), followed the same year by a short cycle soybean (from early January to May-June). To limit the pressure of weeds before sowing, the cereals and the long cycle soybean are preceded by a few months of "chemical fallow" in the course of which three herbicides are applied (including two glyphosates and a complementary herbicide for glyphosate-tolerant weeds). During the cultivation of the long cycle soybean, two applications of glyphosate and one of 2.4DB are also made, supplemented by a preventive insecticide and an application of toxic bait to prevent woodlice and slugs from developing in the mulch. On the short cycle soybean, only three applications of glyphosate are systematically made between sowing and March. Of the two soybean crops, only the long cycle one is fertilized (nitrogen and phosphorus), as producers consider that the short cycle soybean can benefit from the fertilization residues of the previous cereal. One or two herbicides are applied during the cereal cycle, and a systematic application of broad spectrum fungicide is made, usually by air.

All the surveys converge: the agronomic logic of this system is based on the motive to reach high economic profitability in the short term. This goal is achieved by immobilizing the minimum of capital (primarily for renting land and for recourse to agricultural contractors for all the practices) and by guarding against any productive risk by the systematic use of chemical inputs to reach satisfactory productivity.

\subsection{Description of the agronomic logic of the five types of alternative cropping systems identified (stages 2 and 3 )}

We identified 22 alternative cropping systems with 15 producers interviewed. Alternative cropping systems differ from the dominant system and from each other by their agronomic logic. They differ from the dominant system by (i) an occasional use of soil tillage, (ii) their frequency of return of soybean in the rotation, (iii) the lengths and diversity of species in their rotations, and (iv) their level of pesticide use. Alternative cropping systems mainly differ from each other by their frequency of return of soybean, potato, fodder crop, or pasture in their rotations and their intensity of pesticide use.

Motives cited by the producers to justify the choice of these alternative practices all go beyond the wish to achieve high economic profitability in the short term, as expected by producers developing the dominant system. They all explain that they manage their productive activity over the medium to long term. Five motives, linked to their original practices, differentiate the alternative systems among them: (i) the expectation of achieving a high return on investment; (ii) of maximizing the land use; (iii) of managing the productive and/or commercial risk; (iv) of spreading the workload over the year, and (v) of reducing the pressure of weeds or pests and the use of pesticides. By clarifying the similarities and differences between cropping systems (practices, motives), we were able to build five types of cropping systems which we named in relation with their agronomic logic: (1) dominant-like systems, (2) diversified-arable systems, (3) fodder crop-based systems, (4) potato-based systems, and (5) pasture-based systems.

\subsubsection{Description of the alternative cropping systems developed by farmers}

The main agronomic characteristics of each type of alternative systems are presented in Table 1 in comparison with the dominant system.

The dominant-like systems (three cropping systems) have crop rotations of an average duration of 3 years, which are more diversified than the dominant system (integration of maize or sunflower), but whose cultivation methods are, like the dominant system, input-intensive (pesticides, fertilizer). In 
Table 1 The dominant system and the different types of alternative cropping systems all differ in their practices, which are presented in this table

\begin{tabular}{|c|c|c|c|c|c|c|c|c|}
\hline $\begin{array}{l}\text { Types of } \\
\text { cropping } \\
\text { systems }\end{array}$ & $\begin{array}{l}\text { Number of } \\
\text { cropping } \\
\text { systems } \\
\text { per type }\end{array}$ & Species cultivated & $\begin{array}{l}\text { Average } \\
\text { length of } \\
\text { rotation } \\
\text { (years) }\end{array}$ & $\begin{array}{l}\text { Average number } \\
\text { of crops (excluding } \\
\text { multiannual grassland) } \\
\text { planted over } 5 \text { years }\end{array}$ & $\begin{array}{l}\text { Number of crops } \\
\text { of soybean in the } \\
\text { rotation over } \\
5 \text { years }\end{array}$ & $\begin{array}{l}\text { Average number } \\
\text { of applications of } \\
\text { glyphosate per } \\
\text { year }\end{array}$ & $\begin{array}{l}\text { Average number } \\
\text { of applications of } \\
\text { pesticides (excluding } \\
\text { herbicides) per year }\end{array}$ & $\begin{array}{l}\text { Use of } \\
\text { tillage }\end{array}$ \\
\hline Dominant & l & Soybean, wheat or barley & 2 & 7.5 & 5 & 4 & 2 & 0 \\
\hline 1 & 3 & $\begin{array}{l}\text { Soybean, wheat or barley, } \\
\text { maize or sunflower }\end{array}$ & 3.3 & 7.2 & 3.8 & 4.1 & 3.2 & 0 \\
\hline 2 & 6 & $\begin{array}{l}\text { Maize, soybean, sunflower, } \\
\text { wheat or barley, oilseed rape }\end{array}$ & 4.3 & 6.3 & 3 & 3.1 & 1.1 & 1 \\
\hline 3 & 5 & $\begin{array}{l}\text { Soybean, oats or ryegrass, wheat } \\
\text { or barley }\end{array}$ & 2.2 & 7.3 & 2.6 & 2.3 & 0.6 & 1 \\
\hline 4 & 3 & $\begin{array}{l}\text { Potato, soybean, wheat, barley, } \\
\text { oilseed rape, maize, sunflower }\end{array}$ & 5 & 6.5 & 2.4 & 2 & 4 & 2 \\
\hline 5 & 4 & $\begin{array}{l}\text { Soybean, maize, sunflower, } \\
\text { multispecific grasslands, } \\
\text { sorghum, wheat, barley, } \\
\text { ryegrass }\end{array}$ & 8 & 5.9 & 1.7 & 1.4 & 0.7 & 2 \\
\hline
\end{tabular}

(1) Dominant-like systems, (2) diversified-arable systems, (3) fodder crop-based systems, (4) potato-based systems, (5) pasture-based systems. Concerning the use of soil tillage, a score equal to 0 means that direct seeding is generalized for all the crops; a score equal to 1 means occasional recourse to superficial tillage (less than $10 \mathrm{~cm}$ in depth); a score of 2 means occasional recourse to major tillage, such as ploughing

this type are the two systems integrating irrigated maize and soybean. All the crops are sown by direct seeding.

The diversified-arable systems (six cropping systems) are characterized by more diversified rotations (4 years on average), with an occasional return of oilseed rape, sunflower, maize, wheat, or barley. In this type, the frequencies of return of soybean into the rotation are much lower than in the dominant system ( 3 out of 5 years instead of 5). Although in certain cases, the level of herbicide use is high, these producers diversify the active matters used and apply few pesticides. In two of the cropping systems of this type, the producers occasionally resort to superficial tillage (every 34 years), which could contribute, in synergy with the longer rotation, to the reduction in pesticide use.

The fodder crop-based systems (five cropping systems) are set up in mixed farms (combining crops and livestock). The rotations are short (2-3 years), but the short cycle soybean of the dominant system is replaced by an annual fodder crop (ryegrass or oats). The number of pesticide applications, used more as a curative, is only half that of the dominant cropping system. Different original practices could favor this low pesticide use: (i) mechanical weeding; (ii) superficial tillage (disc tiller), in some years, to loosen the soil packed by animals when grazing the fodder crop; or (iii) with one producer, a tedder to turn the mulch and expose pests (woodlice, slugs) to predation by birds.

In the potato-based systems (three cropping systems), the rotation is extended and diversified with maize, wheat, barley, oilseed rape, and oats but also by the regular cropping (every 5 years) of potato; the land is ploughed before and after this crop. Potato cultivation, from planting to harvest, is entirely managed by a third party to whom the owner rents his land for a year. The fertilization level and use of fungicides and insecticides are very high on the potato. Because of tillage and the extended rotation, the use of glyphosate is reduced, but because of the potato, the number of pesticide applications is rather high.

In the pasture-based systems (four cropping systems), set up in mixed farms, the highly diversified succession of arable crop species (cereals and oilseeds) is regularly interrupted by 2 to 5 years of multiannual grassland, including legumes. The frequency of return of soybean in the rotation is the lowest. The occasional recourse to tillage (in particular to turn over the grasslands before returning to cropping), the diversification of species, and the integration of multiannual grasslands could contribute to limiting the use of pesticides, which can be nil in some years.

\subsubsection{Analysis of producer motives justifying the choice of alternative systems}

By clarifying the motives which lead them to implement these alternative cropping systems, the producers quoted criteria for assessing their practices which came down to economic, organizational, and agro-environmental performances that we present in Table 2, in comparison with the criteria for assessing the dominant system.

The 15 producers interviewed, who cultivate on land which belongs to them, are all attentive to maintaining the mediumterm fertility of their lands and thereby justify their choice of diversifying the productions in their rotations. Some of them explain that they give an important role to cereals (wheat, barley, maize), as they expect their high carbon/nitrogen ratio organic residues to contribute to maintaining the soil carbon content. By diversifying, the producers of diversified-arable, fodder crop-based, and pasture-based systems also seek to 
Table 2 The performance criteria quoted by the actors interviewed, which justify the choice of their practices, are different when they concern the alternative or the dominant cropping systems

\begin{tabular}{|c|c|c|c|c|c|c|}
\hline Performance criteria & $\begin{array}{l}\text { Dominant } \\
\text { system }\end{array}$ & $\begin{array}{l}\text { Dominant- } \\
\text { like } \\
\text { systems }\end{array}$ & $\begin{array}{l}\text { Diversified- } \\
\text { arable } \\
\text { systems }\end{array}$ & $\begin{array}{l}\text { Fodder crop- } \\
\text { based } \\
\text { systems }\end{array}$ & $\begin{array}{l}\text { Potato- } \\
\text { based } \\
\text { systems }\end{array}$ & $\begin{array}{l}\text { Pasture- } \\
\text { based } \\
\text { systems }\end{array}$ \\
\hline Maximization of added value per hectare (GAV) & + & ++ & ++ & ++ & ++ & ++ \\
\hline Maximization of return on investment (ROI) & ++ & + & 0 & 0 & 0 & 0 \\
\hline Maximization of land use (Land use) & ++ & + & + & ++ & 0 & 0 \\
\hline Reduction of economic risks (Risk) & + & ++ & ++ & + & ++ & ++ \\
\hline Spread of work load over the year & 0 & 0 & + & + & ++ & ++ \\
\hline Maintenance of soil organic fertility in the long term (IOC) & 0 & ++ & ++ & ++ & ++ & ++ \\
\hline Reduction of weed populations and herbicide use (TFI herbi.) & 0 & 0 & + & + & 0 & 0 \\
\hline $\begin{array}{l}\text { Reduction of pressure from pests and the use of other pesticides } \\
\text { (TFI without herbi.) }\end{array}$ & 0 & 0 & + & ++ & ++ & + \\
\hline
\end{tabular}

Most of the criteria quoted correspond to an indicator (specified in brackets) used in the assessment stage. 0 Criterion not mentioned by those interviewed; + criterion mentioned but not as a priority; ++ criterion regularly mentioned as being a priority. Each note corresponds to the medium note for the type

reduce health risks and the use of pesticides on their fields. Most of the producers (diversified-arable, fodder crop-based, potato-based, and pasture-based systems) add that diversification enables them to distribute their workloads throughout the year and to reduce economic risks. Producers developing diversified-arable, potato-based, and pasture-based systems seek to spread the dates for sowing short cycle soybean to limit climatic risks. To this end, they sow soybean after wheat and barley but also after oilseed rape which frees the land even earlier. Producers developing diversified-arable systems grow soft wheat and durum wheat or malting barley and fodder barley to spread commercial risks. The potato, by the annual fixed return that it ensures, also constitutes a risk reduction factor. At the crop scale, tenants of the dominant-like systems try to reduce biotic productive risks using systematic applications of chemical inputs.

The producers who have livestock on their farm (fodder crop-based and pasture-based systems) highlight their interest in this activity, which they say ensures they have an income less prone to climatic risks than arable crops. The integration of fodder crops into the rotation, low in inputs and working time, represents, like short cycle soybean, an additional production for the farmer who can compensate for a bad harvest of the previous crop. It also increases his self-sufficiency in forage for the herd. Some also see this crop as an opportunity to maintain constant plant cover on their field, for erosion prevention. As for multiannual grasslands (pasture-based systems), the producers explain that they guarantee constant plant cover and fulfill the double objective of providing fodder for the herd throughout the year and of maintaining soil fertility.

In order to limit both their intermediate consumptions and environmental pollutions, some producers (diversified-arable, fodder crop-based, and pasture-based systems) explain that they prefer to adapt their practices to the state of the observed crop and soil rather than to systematize direct seeding or pesticide applications. For this, they make regular inspections in their fields, to start curative applications of pesticides, to decide occasional recourse to soil tillage or to turn over the mulch. On the other hand, in the dominant-like systems (as in the dominant system), to save time and simplify the work, direct seeding and systematic applications of pesticides are preferred to inspections in the field, judged to be very time-consuming.

\subsection{Results of the performance assessment of alternative cropping systems and of the dominant system (stage 4)}

Figure 2 shows the results of the multicriteria assessment by type of cropping system. The results of the indicators of ammonia volatilization, nitrogen protoxide emissions, nitrate leaching, and energy consumption are not presented here, because they are very similar, and low, for all the systems.

The gross added value and return on investment results are sensitive to variations in yield. The data mobilized for calculations do not come from precise measurements but from estimates provided by the producers, and the averages are calculated on small samples. For these reasons, we will only propose an analysis of the general trends for these two indicators.

Gross added value: the dominant-like systems have the highest result, the other systems being similar. The high result of this type is due to high yields, helped by the possibility of irrigating certain crops (maize and, in certain cases, short cycle soybean). The other types of systems, not irrigated, reach comparable economic performances in several ways: (i) the dominant system shows the most intensive land use and every year includes soybean in the rotation; (ii) the diversified- 
arable, fodder crop-based, and pasture-based systems, characterized by diversified rotations, have lower average levels of input use; and (iii) the potato-based systems obtain this result thanks to the potato, which generates a high fixed annual income (land rental). According to the farmers, potato cultivation leaves nitrogen residues to the following crop, ensuring high yields (wheat, maize, or sunflower).

Return on investment: even if the producers do not look to maximize the return on investment, the fodder crop-based and pasture-based systems obtain the highest result, followed closely by the dominant system. The dominant-like systems have the lowest result. As sought by the producers who implement it, the dominant system has quite a high result, as the soybean, which returns to the field every year, is a species that requires little fertilization. The good result of the fodder crop-based systems is explained by the integration into the rotation, every 2 or 3 years, of low-input fodder crops (few or no pesticides and low fertilization). As for the annual crops of pasturebased systems (without the years of grassland in the calculation), we can put forward the hypothesis that crop diversification in the rotation and the years of grassland increase the potential for biotic regulation and soil fertility, which explains the low level of input use on the arable crops (pesticides and fertilizer). On the other hand, the poor result of the dominant-like systems is related to a very high level of input use on the fields (pesticides and fertilizer).

Risk: if we exclude the potato-based systems, favored by the income from renting land to a third party approximately every 5 years, diversified-arable, fodder crop-based, and pasture-based systems have the lowest risk levels - crop diversification, as sought by the producers, goes in the direction of risk reduction (productive and commercial). In coherence with their slightest sensitivity to risk (Table 2), the dominant and the dominant-like systems are the riskiest. The short cycle soybean (present in the rotation every 2 years to maximize land use) is indeed a risky crop, sown late following a cereal (harvested from December to the beginning of January). Its yield can be greatly affected by drought and by frost in early autumn.

Maximization of land use: diversified-arable and potatobased systems have the lowest level of land use. The dominant and the pasture-based systems have the highest levels of land use, closely followed by the dominant-like and fodder cropbased systems. It is the presence of grasslands or of double cropping in the rotation which ensures this intensive land use.

Organic carbon in the soil: the results of the organic carbon indicator are in all cases higher for the alternative systems than for the dominant system. As sought by the producers, diversifying the species or integrating multiannual grassland into the rotation make it possible to maintain high organic carbon in the soil over the long term. On the other hand, as confirmed by the result of the dominant system, cultivating soybean on the same field every year, even using direct seeding, does not provide enough organic carbon input to keep these contents stable (Studdert and Echeverria 2000). Among the diversified systems, the potato-based systems have the lowest result, which can be explained by the recourse to ploughing for planting and harvesting the potato.

TFI (with herbicides, without herbicides) and glyphosate tolerances: the dominant-like and the dominant systems have among the highest results on the two TFI indicators (results close to the radar center on Fig. 2). The diversified-arable, fodder crop-based, and pasture-based systems have the lowest TFI results. As sought by the producers who practice it, and as shown by some authors, the diversification of species (Altieri 1995; Wezel et al. 2013) and/or the occasional recourse to tillage make it possible to limit biotic pressure. In the potatobased systems, although producers try to reduce the pressure of pests and/or the use of pesticides on diversified crops, the high level of the TFI without herbicides can be ascribed to the potato crop. The results of the tolerance indicator follow the trend of the results of the TFI indicator for herbicides (where glyphosate is dominant) for all the types. Figure 3 specifies this result, returning to the level of the 22 elementary systems and taking into account only the use of glyphosate. On all of the cropping systems studied, the number of glyphosate applications is higher in situations where the frequency of soybean in the rotation is high: it is in these situations that the development of tolerant weeds leads producers to use other herbicides on soybean and fallow, in addition to glyphosate (red diamonds on Fig. 3).

\subsection{Lessons "from" and "on" the tracking on-farm sustainable systems approach (stage 5)}

\subsubsection{Lessons "from" the tracking: analysis of the conditions for developing the most effective systems and their potential interest for the future}

The analysis of the economic and agro-environmental indicators suggests that some of the alternative cropping systems are more sustainable at some levels than the dominant system. Under what conditions would they be likely to replace the dominant system?

The fodder crop-based and pasture-based systems closely associate arable crops and the production of cattle feed. In recent years, however, the lack of competitiveness in extensive livestock farming and restrictions on meat exports caused a decline in livestock farming (Elverdín et al. 2011). The return to systems associating crops and livestock would suppose an intense evolution of price ratios between animal and plant products, a desire to reinvest in building up herds and to acquire new skills. In this economic situation, the fodder cropbased and pasture-based systems are addressed primarily to 
a

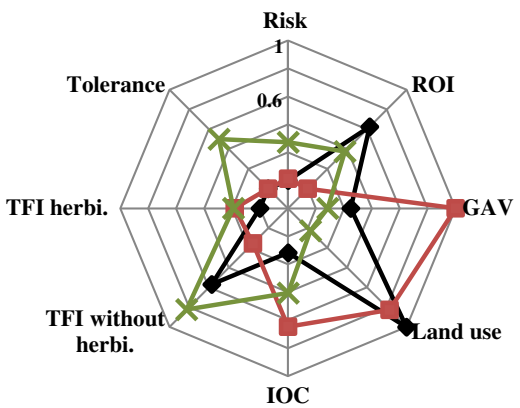

Fig. 2 The assessment indicators show that some of the alternative cropping systems are more sustainable than the dominant system a dominant system black diamond, dominant-like systems red square, and diversified-arable systems green cross; $\mathbf{b}$ dominant system black diamond, fodder crop-based systems orange star, potato-based systems blue circle, and pasture-based systems green triangle. For the tolerance indicator, we have represented, by type, the percent of scores equal to 3 (no presence of tolerant weeds identified on the fields). The results of the

producers who, by taste or obligation (use of land unsuitable for crops), have maintained livestock farming systems. These farmers stress the interest of integrating fodder plants into the rotations within the cultivated area, when in pampean mixed farms the trend is to separate lands dedicated to crops and livestock (Manuel-Navarrete et al. 2005).

The diversified-arable and potato-based systems only include cash crops. But what room is there today for diversification crops in Argentina? The potato, emblematic of the study area, is moving towards areas where the land is more suitable. Just before the time of the study, just like beef, wheat and maize came under export restriction policies, to stimulate pig and poultry production (maize) and ensure national food sovereignty (wheat). Barley appears as a substitution crop for wheat and is finding commercial outlets in national brewery industries and as fodder cereal at international level. Sunflower is an interesting diversification crop, established on a stable

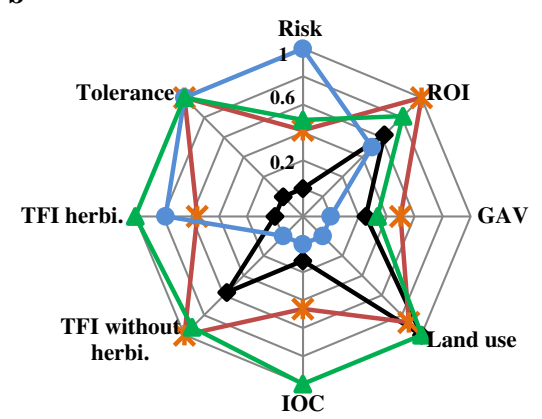

indicators were put on the graph at a scale of [0-1] (1 being the most effective result). The five types come in the following ranges of real values: risk (\%) $[36.4 ; 52.5]$; return on investment (ROI, $\$ / \$ /$ ha) $[1.4$; 3]; gross added value (GAV, hundreds of $\$ /$ ha) $[7.2 ; 8.4]$; land use intensity (land use, \%) [68.1; 79.2]; indicator of organic carbon content (IOC) $[14.2 ; 15.9]$; Treatment Frequency Index herbicides (TFI herbi.) $[2.1 ; 6]$; Treatment Frequency Index without herbicides (TFI without herbi.) $[0.6 ; 4.7]$; tolerance $(\% 3)[0 ; 100]$

market and well controlled at the technical level. At the time of the study, this was not the case for oilseed rape; the farmers were in a learning phase, testing various practices and insertions into rotations. Lengthening the rotations with cereals and oilseed crops therefore seems easier to achieve than the redevelopment of livestock farming, but it would undoubtedly require an evolution in the agricultural policies currently very favorable to the soybean (Manuel-Navarrete et al. 2005; Botta et al. 2011). However, the assessment of the diversified-arable systems cannot be regarded as being really satisfactory, and improvements must be worked on, in particular to increase the gross added value and reduce pesticide use.

The tracking does not lead only to the identification of alternative systems: the analysis of the relationships between producer motives, technical choices, and performances also makes it possible to identify several agronomic levers which could be mobilized to invent other original and effective
Fig. 3 The increasing implementation of soybean in rotations ( $x$-axis) increases the number of glyphosate applications per year ( $y$-axis) and at the same time the glyphosatetolerant weed development. Linear adjustment $R^{2}=0.5482$
Frecuency of return of soybean in the rotation

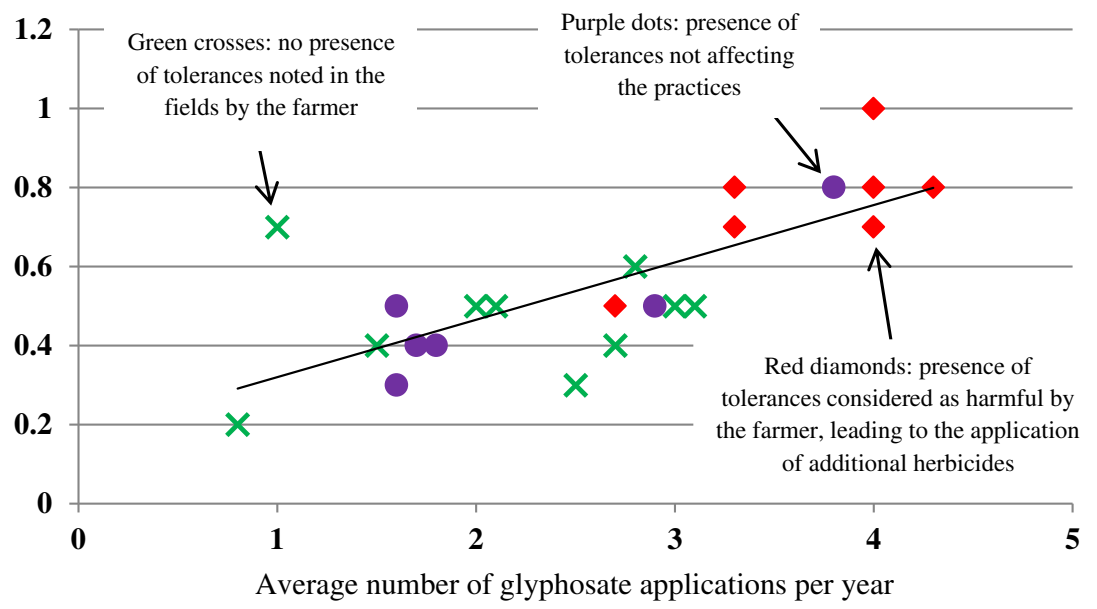


systems and thus improve the sustainability of production methods in the Pampa:

- Diversification of species and lengthening the rotations (in fodder crop-based, potato-based, and pasture-based systems) seem to be effective solutions to avoid the development of glyphosate-tolerant weeds, a major problem in the Pampa.

- The reintroduction, targeted and occasional, of superficial tillage in a region where the continuous practice of direct drilling has become a dogma, is justified by producers who observe their fields on a regular basis (diversifiedarable and fodder crop-based systems). For these producers, the combination of direct seeding and occasional use of tillage makes it possible to combine the benefit of direct seeding during a large part of the rotation and those of tillage to prevent weed invasion or to loosen a compacted surface.

- The use, in a fodder crop-based system, of a tedder during intercropping to turn over the mulch, to expose the slugs and woodlice hidden there and enable predatory birds to find and eat them, is one response to the increasing damage caused by these pests in the region. This damage has been stressed by several other producers, who use pesticides to control them. It is not certain that this method is effective, but at least it enriches the panoply of alternatives to pesticides that agronomists could test.

\subsubsection{Lessons "on" the tracking on-farm sustainable systems approach}

This work allowed us to make progress in setting up a method aiming at capitalizing references on alternative cropping systems developed by producers in their fields. The identification phase by networks of actors proved to be effective in identifying original systems. However, we noted that it was necessary to diversify the types of networks mobilized and not confine ourselves to those usually mobilized by local researchers or advisors; that way, we would only encounter similar systems or systems that are already partly known. It would appear interesting to look further into and better formalize this identification phase in future works, insofar as it greatly conditions the tracking results. Other works aim to describe the motives driving the choices of producers when developing original practices (Feike et al. 2010). Beyond a description, we sought, in this work, to transcribe these motives into assessment criteria and also looked to clarifying the link between "motives" and "practices" (agronomic logic). This attention paid to the producers' criteria is in line with suggestions encountered in different works carried out in Argentina (Vega et al. 2015; Sarandón and Flores 2009). We outline that the sets of prefabricated indicators, used in many works to assess the multiperformance of systems (Girardin et al. 1999; Van der Werf and Petit 2002), may not contain indicators that are essential for the producers.

\section{Conclusion}

This work identified alternative cropping systems in a territory described by many as homogeneous.

These alternative systems differ from the dominant one in their agronomic logics. By describing the cropping systems, we pointed out original practices developed by farmers. These practices could contribute to improving their agrienvironmental performances: diversification of rotations, occasional use of superficial tillage, and reasoning of chemical applications by monitoring. We also pointed out that the motives driving the choices of their practices are different between the producers developing the dominant and alternative systems; as for the latter, they manage their activity over the long term. Comparing the assessment results showed that some of the original systems were more sustainable than the soybean-based system: lower economic risk level, better ability to maintain soil organic carbon content, and less glyphosate-tolerant weed development. The analysis and assessment of these systems, crossed with an analysis of their conditions of development, enabled us to shed light on original production methods which could constitute sources of inspiration to develop sustainable cropping systems in the Argentinean Pampa.

These results are based on a small sample: by construction, tracking alternative systems only makes it possible to locate a small number of producers, especially in a region where a dominant system is practiced by the vast majority of them. More than to duly validated innovations, tracking leads to the identification of paths of action, which would deserve to be studied more thoroughly by setting up measurements in the producers' fields and by carrying out experiments. The method employed and our results show that the characterization of cropping systems cannot be limited to a simple description of practices: only an analysis of the links between practices, motives (analysis of agronomic logics), and performances makes it possible to shed light on innovative solutions which can be mobilized by other farmers or studied by agronomists.

Acknowledgements This work, carried out in the framework of the International Agriterris program, was financed by the INRA (SAD division), the INTA (Balcarce), and the ANR (Interra project). We thank the colleagues of INTA (F. Andrade, M. Mosciari, and G. Studdert), of INRA (C. Albaladejo, S. Chaxel, and P. Gasselin), of AACREA (J. GonzalesMontaner and N. Tagle) who made this work possible, as well as all the producers, contratistas, and advisors who participated in the survey. We also thank A. Duparque (AgroTranfert Ressources et Territoires) and C. Bockstaller (INRA) for their methodological support (SIMEOS AMG and INDIGO ${ }^{(B)}$ V2.0 software). 


\section{References}

Albaladejo C (2011) Les transformations de l'espace rural pampéen face à la mondialisation. Annales de Géographie 686:387-409. doi:10. 3917/ag.686.0387

Altieri MA (1995) Agroecology: the science of sustainable agriculture. Westview Press, Boulder

Altieri MA, Funes-Monzote FR, Petersen P (2012) Agroecologically efficient agricultural systems for smallholder farmers: contributions to food sovereignty. Agron Sustain Dev 32:1-13. doi:10.1007/s13593011-0065-6

Andrade F, Sadras VO (2002) Bases para el manejo del maíz, el girasol y la soybean. INTA-Universidad de Mar del Plata, Balcarce

Andriulo A, Mary B, Guérif J (1999) Modelling soil carbon dynamics with various cropping sequences on the rolling pampas. Agronomie 19:365-377. doi:10.1051/agro:19990503

Barral MP, Maceira NO (2012) Land-use planning based on ecosystem service assessment: a case study in the Southeast Pampas of Argentina. Agric Ecosyst Environ 154:34 43. doi:10.1016/j.agee. 2011.07.010

Benton TG, Vickery JA, Wilson JD (2003) Farmland biodiversity: is habitat heterogeneity the key? Trends Ecol Evol 18:182-188. doi: 10.1016/S0169-5347(03)00011-9

Bockstaller C, Girardin P, Van der Werf HGM (1997) Use of agroecological indicators for the evaluation of farming systems. Eur $\mathrm{J}$ Agron 7:261-270. doi:10.1016/S0378-519X(97)80032-3

Botta GF, Tolón-Becerra A, Lastra-Bravo X, Tourn MC (2011) A research of the environmental and social effects of the adoption of biotechnological practices for soybean cultivation in Argentina. Am J Plant Sci 2:359-369. doi:10.4236/ajps.2011.23041

Brunet N, Guichard L, Omon B, Pingault N, Pleyber E, Seiler A (2007) L'indicateur de fréquence de traitements (IFT) : un indicateur pour une utilisation durable des pesticides. Courrier de l'environnement de l'INRA 56: 13-24 http://www7.inra.fr/dpenv/pdf/brunetc56.pdf (Access date: 21.09.2015)

Cámara de sanidad agropecuaria y fertilizantes (2007) Guía de productos fitosanitarios para la república Argentina. Tomo 1 y 2. CASAFE, Buenos Aires. 2248p. http://www.casafe.org/ (Access date: 21.09. 2015)

Carreño LV, Pereyra H, Ricard MF (2010) Captura y emisión de gases de efecto invernadero. In: Viglizzo EF, Jobbágy EG (Ed) Expansión de la Frontera Agropecuaria en Argentina y su Impacto EcológicoAmbiental. INTA, Buenos Aires, pp 31-36 http://inta.gob.ar/ documentos/expansion-de-la-frontera-agropecuaria-en-argentina-ysu-impacto-ecologico-ambiental/

Castilla F (2013) Siembra directa, la elegida para conservar el suelo. RIA $30-2: 118-123$

Costa JL, Aparicio V, Zelaya M, Gianelli V, Bedmar F (2010) Transporte de glifosato en el perfil de un suelo del sudeste bonarense. In: Camino M, Aparicio V (Ed) Aspectos ambientales de luso de glifosato. INTA, Buenos Aires, pp 95-101 http://inta.gob.ar/ documentos/aspectos-ambientales-del-uso-del-glifosato

Duparque A, Tomis V, Mary B, Boizard H, Damay N (2011) Le bilan humique AMG. Pour une démarche de conseil fondée sur des castypes régionaux. 10ème rencontre de la fertilisation raisonnée et de l'analyse. COMIFER-GEMAS ; Reims, 23-24 Novembre 2011. 19p. http://www.comifer.asso.fr/images/pdf/10emes_rencontres/ duparque $/ 5 \% 20$ - $\% 20$ agro $\% 20$ transfert $\% 20$ - $\% 20$ annie $\%$ 20duparque \%20-\%20article.pdf (Access date: 21.09.2015)

Elverdín JH, Maggio A, Muchnik J (2011) Facteurs d'ancrage territorial des activités agricoles Soja et élevage en Argentine. Écon rural 322: 64-78. doi:10.4000/economierurale.2962
Feike T, Chen Q, Graeff-Hönninger S, Pfenning J, Claupein W (2010) Farmer-developed vegetable intercropping systems in southern Hebei, China. Renewable Agric Food Syst 25:272-280. doi:10. 1017/S1742170510000293

Filloy J, Bellocq M (2007) Patterns of bird abundance along the agricultural gradient of the Pampean region. Agric Ecosyst Environ 120: 291-298. doi:10.1016/j.agee.2006.09.013

Girardin P, Bockstaller C, van der Werf H (1999) Indicators: tools to evaluate the environmental impacts of farming systems. J Sustain Agric 13-4:5-21. doi:10.1300/J064v13n04 03

Goulet F, Pervanchon F, Conneau C, Cerf M (2008) Les agriculteurs innovent par eux-mêmes dans leurs systèmes de culture. In: Reau $\mathrm{R}$, Doré $\mathrm{T}$ (eds) Systèmes de culture innovants et durables :quelles méthodes pour les mettre au point et les évaluer? Educagri, Dijon, pp 53-69

Hernández V (2009) Ruralidad y el paradigma de los agronegocios en las pampas gringas. In: Gras C, Hernández V (eds) La Argentina rural. De la agricultura familiar a los agronegocios. Biblos, Buenos Aires, p $18 \mathrm{p}$

Manuel-Navarrete D, Gallopín G, Blanco M, Días-Zorita M, Herzer H, Laterra P, Morello J, Murmis MR, Pengue W, Piñeiro M, Podestá G, Satorre EH, Torrent M, Torres F, Viglizzo EF, Caputo MG, Celis A (2005) Análisis sistémico de la agriculturización en la pampa húmeda argentina y sus consecuencias en regiones extrapampeanas: sostenibilidad, brechas de conocimiento e integración de políticas. Publicación de las Naciones Unidas, Santiago de Chile: 65p. http:// repositorio.cepal.org/bitstream/handle/11362/5656/S051013_es. pdf? sequence $=1$ (Access date: 13.10.2015)

Meynard JM, Dedieu B, Bos AP (2012) Re-design and co-design of farming systems. An overview of methods and practices. In: Darnhofer I, Gibon D, Dedieu B (eds) Farming systems research into the 21st century: the new dynamic. Springer, Netherlands, pp 407-432. doi:10.1007/978-94-007-4503-2

Monaco M, Laclau P (2013) Caracterización de la oferta de recursos forestales del partido de Balcarce, provincia de Buenos Aires. RIA 39-2: 149-161 http://ria.inta.gov.ar/?p=3956 (Access date : 21.09 . 2015)

Petit MS, Reau R, Dumas M, Moraine M, Omon B, Josse S (2012) Mise au point de systèmes de culture innovants par un réseau d'agriculteurs et production de ressources pour le conseil. Innovations Agronomiques 20 : 79-100 http://www6.inra.fr/ciag/ Revue/Volumes-publies-en-2012/Volume-20-Juillet-2012 (Access date: 21.09 .2015$)$

Sarandón SJ, Flores CC (2009) Evaluación de la sustentabilidad en agroecosistemas: Una propuesta metodológica. Agroecología 5: 33-40. http://revistas.um.es/agroecologia/article/view/117131/ 110801 (Access date: 12.10.2015)

Studdert G, Echeverria H (2000) Crop rotations and nitrogen fertilization to manage soil organic carbon dynamics. Soil Sci Soc Am J 64: 1496-1503. doi:10.2136/sssaj2000.6441496x

Van der Werf HMG, Petit J (2002) Evaluation of the environmental impact of agriculture at the farm level: a comparison and analysis of 12 indicator-based methods. Agric Ecosyst Environ 93:131-145. doi: 10.1016/S0167-8809(01)00354-1

Vega ML, Iribarnegaray MA, Hernández ME, Arzeno JL, Osinaga R, Zelarayán AL, Fernández DR, Mónico Serrano FH, Volante JN, Seghezzo L (2015) Un nuevo método para la evaluación de la sustentabilidad agropecuaria en la provincia de Salta, Argentina. RIA 41-2: 168-178 http://ria.inta.gov.ar/?p=7465 (Access date: 21.09.2015)

Wezel A, Casagrande M, Celette F, Vian JF, Ferrer A, Peigné J (2013) Agroecological practices for sustainable agriculture. A review Agron Sustain Dev 34:1-20. doi:10.1007/s13593-013-0180-7 